\title{
Karlovy Vary 2001
}

\author{
By Ron Holloway
}

Spring 2002 Issue of KINEMA

\section{KARLOVY VARY INTERNATIONAL FILM FESTIVAL 2001}

It came as no surprise when Jean-Pierre Jeunet's inventive Le fabuleux destin d'Amélie Poulain (Amélie from Montmartre, France) was awarded the Crystal Globe the 36th Karlovy Vary International Film Festival (514 July 2001) by an international jury headed by Poland's Krzysztof Zanussi. All the more so since this delightful comédie humaine -- about the dream world of a young waitress (Audrey Tautou) working at a bistro in Montmartre, who one day finds a hidden box full of childhood treasures in her apartment -- is currently a runaway box office hit in France. Just as impressive, however, was Robert Glinski's Czes Tereska (Hi, Tereska, Poland), awarded both the Special Jury Prize and the International Critics (FIPRESCI) Prize. This poignant portrait of a young girl seeking sexual and emotional stability in an environment that only restricts fulfilment came across as an authentic statement due to the director's decision to shoot his fictiondocumentary in black-and-white and to choose nonprofessionals to play the lead roles.

Karlovy Vary had its controversial moments as well. Several critics felt that Ibolya Fekete's Chico, a Hungarian-German-Croatian-Chilean coproduction awarded Best Director by the international jury and the Ecumenical Prize, offered specious arguments in defence a pro-nationalist Croatian mercenary code during the recent Balkan war. By contrast, Darko Baji's War Live, the Yugoslav competition entry, reduced the NATO bombing of Belgrade to a rather amusing black comedy about a harried film director wrestling with a government secret service agent to complete a production that, in the end, would condemn the Slobodan Miloševi regime for leading the country down the road to moral disaster. Not even the well attended press conferences removed the suspicion that both directors appeared unsure as to where they actually stood on the Balkan questions still posed by politicians and journalists daily in the media.

Double acting awards were given to the lead protagonists, Sven Wollter and Viveka Seldahl, in Bille August's En säng för Martin (A Song for Martin, Denmark-Sweden), an Alzheimer tale about an afflicted orchestral conductor and his ever-suffering wife. As good as these performances are, and as loud as applause was as the credits rolled up, you went away with the feeling that Bille August loss ground steadily over the long stretch by refusing to budge from a one-note emotional chord from beginning to end. Moreover, René Zellweger as the hapless, wacky, romance-smitten lead in Sharon Maguire's Bridget Jones's Diary (UK-USA) outshone all performances in the Official Selection (save perhaps for inimitable Audrey Tautou) -- too bad the comedy ran out-of-competition.

For some obscure reason, the Asian selection was weak at Karlovy Vary in a year of strength at other major festivals. Still, Iran cinema made its presence felt in other ways. Jury member Jafar Panahi was honoured with a warmly received three-film tribute: Badkonake sefid (The White Balloon, 1995), Ayneh (The Mirror, 1997), and Dayereh (The Circle, 2000), the last named the Golden Lion winner at Venice. And Rakhshan Bani Etemad's Zir-e poust-e shahr (Under the Skin of the City), the portrait of a working-class mother struggling to hold her family together on the eve of parliamentary elections despite a gullible husband and a wastrel son, was awarded the NETPAC Prize "for capturing the impact of new reforms on a changing Iranian society and for its artistic treatment of complex issues." Also, a new era of social commitment and changing times is clearly visible in Vietnamese cinema. Dang Nhat Minh's Mua oi (The Season of Guavas) chronicles the inner pain of a middle-aged man lost in his memories of a more pleasant childhood -- before his parents suffered the loss of property under the new government at the end of the Vietnam war. And Uyen Luu's sensitive Pho (Noodle Soup, Vietnam-UK), awarded Best Short Documentary, sketches a 23-year-old girl's mixed inner feelings as she returns for a visit to Saigon, the city she had left as a little girl to emigrate abroad with her mother.

Slotted this year on the festival calendar immediately after Moscow, instead of before, the 36th KVIFF aimed mightily to boost it's A-category status. Under president Jií Bartoška and artistic director Eva Zaoralová, the festival committee raised a reported budget of $\$ 2.5$ million that included added support from patrons (Philip Morris, eský Telecom, Premiere) and the presence of newly opened deluxe hotels, first-class restaurants, and 
renovated movie venues but a short walking distance from each other. Add to this the promising revival of New Czech Cinema -- current productions by Jan Svrák, Petr Zelenka, Saša Gedeon, Jan Hebejk and David Ondíek currently command a healthy $35 \%$ of the home box office -- and you have an event that suffers only from a slight lack of hotel space during the opening and closing night galas.

\section{References}

\section{AWARDS}

International Competition

Karlovy Vary Crystal Globe (Grand Prix): Jean-Pierre Jeunet's Le fabuleux destin d'Amélie Poulain (Amélie from Montmartre, France)

Special Jury Prize: Robert Glinski's Cze Tereska (Hi, Tereska, Poland)

Best Director: Ibolya Fekete, Chico (Hungary-Germany-Croatia-Chile)

Best Actress: Viveka Seldahl, En sång för Martin ( A Song for Martin, Denmark-Sweden)

Best Actor: Sven Wollter, En sång för Martin (A Song for Martin, Denmark-Sweden)

Special Jury Mentions: Maziar Miri's Qateh-ye nataman (Unfinished Song, Iran) and Maryse Sistach's Perfume de violetas (Violet Perfume, Mexico)

Documentary Competition

Alain Cavalier's Vies (Lives, France) (over 30 minutes)

Uyen Luu's Pho (Noodle Soup, Vietnam) (under 30 minutes)

Special Mentions: Helena Teštíková's eny na pelomu tisíciletí -- V pasti (Women at the End of the Century, Czech Republic) and photographer Pavel Kostomarov on Sergei Loznitsa's Poselenie (The Settlement, Russia)

International Critics (FIPRESCI) Prize

Robert Glinski's Cze Tereska (Hi, Tereska, Poland)

Ecumenical Prize

Ibolya Fekete's Chico (Hungary-Germany-Croatia-Chile)

NETPAC Award

Horizons Section: Rakhshan Bani Etemad's Zir-e poust-e shahr (Under the Skin of the City, Iran)

Don Quixote Award (International Federation of Film Clubs)

Maryse Sistach's Perfume de violetas (Violet Perfume, Mexico)

Philip Morris Freedom Prize

East of the West Section: Artur Aristakisian's Mesto na zemlye (A Place on Earth, Russia)

Lifetime Achievement Awards

"Ben Kingsley (UK) and Otakar Vávra (Czech Republic)

Karlovy Vary Region Prize

"Marie-José Nat (France)

Prize of Town of Karlovy Vary

Bigas Luna (Spain)

\section{Author Information}

Ron HOLLOWAY (1933-2009) was an American critic, film historian, filmmaker and correspondent who adopted Europe as his home in the early fifties and spent much of his life in Berlin. He was an expert on the study of German cinema and against all odds produced, with his wife Dorothea, the journal German Film, 
keeping us up-to-date with the work of directors, producers and writers and the showing of German films around the world.

In 2007, Ron Holloway and his wife were awarded the Berlinale Camera Award. Ron also received the Bundesverdienstkreuz (German Cross of Merit), Polish Rings, Cannes Gold Medaille, the American Cinema Foundation Award, the Diploma for Support of Russian Cinema and an honorary award from the German Film Critics' Association.

Ron was also a valued contributor to Kinema for the past fifteen years. 